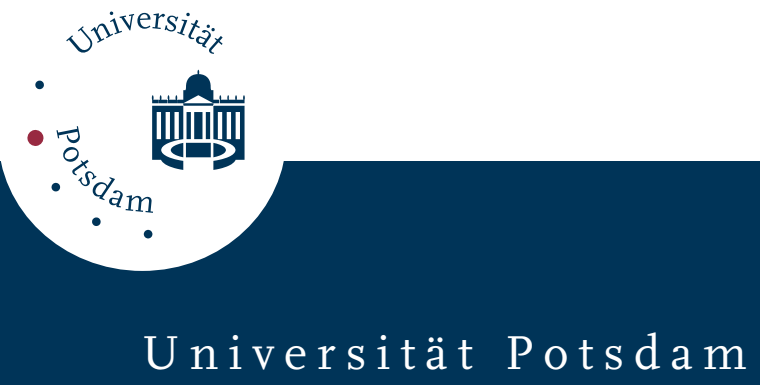

Margret Selting

\title{
The role of intonation in the organization of repair and problem handling sequences in conversation
}

first published in:

Journal of pragmatics. - 12 (1988) 3, S. 293-322, ISSN 0378-2166, DOI 10.1016/0378-2166(88)90035-5

Postprint published at the Institutional Repository of the Potsdam University:

In: Postprints der Universität Potsdam

Philosophische Reihe ; 54

http://opus.kobv.de/ubp/volltexte/2010/4199/

http://nbn-resolving.de/urn:nbn:de:kobv:517-opus-41992

Postprints der Universität Potsdam

Philosophische Reihe ; 54 


\title{
THE ROLE OF INTONATION IN THE ORGANIZATION OF REPAIR AND PROBLEM HANDLING SEQUENCES IN CONVERSATION
}

\author{
Margret SELTING*
}

Received September 1986; revised version November 1987

Transcripts of repair and/or problem handling sequences from natural conversations are presented and analyzed with special reference to the role of intonation in the interactive organization of these sequences. It is shown that (a) in the initiation of so-called repair or local problem handling sequences, intonation is used as a type-distinctive device, and (b) in the handling of a global problem handling sequence, intonation is systematically used as a means to constitute and control participant cooperation. In general, intonation is analyzed as one contextualization cue cooccurring with specific syntactic, semantic and discourse organizational devices to signal the status of an utterance in conversational context. It is hypothesized that especially in the global problem handling sequence, different categories of intonation, i.e. different accent and contour types, are systematically used to signal and control participants' interactive problem handling in different, indexically relevant ways simultaneously.

\section{Introduction}

In discourse and conversational analysis, intonation seems to be frequently looked upon as an additional and redundant means of signalling information which is in principle also expressed in other components of utterances. As a result, intonation is mostly only noted ad hoc; analyses of conversation seldom refer to intonations as structures underlying functional ascriptions of meanings to utterances.

If, however, one aim of conversational analysis in linguistics is the explication of the systematic formal structural devices which functional interpretations are based on, intonation as a prime component of spoken language ought not to be neglected. The incorporation of intonation in conversation analysis can lead to a refinement of received analytical categories and to a sharpened view of verbal interaction in conversations.

In this paper, I want to present extracts from natural conversations in German and analyze the role of intonation with respect to the organization of conversational sequences. In particular, I want to show

* Author's address: M. Selting, Universität Oldenburg, Fachbereich 11, Postfach 2503, D-2900

Oldenburg; West Germany. 
(1) that intonation is systematically used as a type-distinctive device in the initiation of so-called repair or local problem handling sequences; and

(2) that intonation is systematically used as a means to constitute and control participants' cooperation in a global problem handling sequence.

The descriptive categories for the auditive analysis and notation of intonation used here and the general conception about the relation of intonation to the locutionary level of utterances have been outlined in Selting (1987d). The definition of accents as given in that paper (p. 782), however, must be modified: Accents are no longer defined as upward and downward movements in relation to a 'baseline', but solely on the grounds of local pitch movements within the accented syllable. Thus, especially ' + ' now denotes an upward 'peak' and/or falling accent in which the syllable kernel is on an FO peak or on a falling slope following a peak; '-' now denotes a downward 'valley' and/ or rising accent in which the syllable kernel is in an FO valley or on a rising slope following a valley. All other categories as outlined in my preceding paper will be taken for granted here. In short, intonation will be analyzed as a contextualization cue (Gumperz (1982)), i.e. as a cue which is used in cooccurrence with particular utterance types in particular turns in conversation to signal and constitute the status of these utterances in conversational context.

The data presented here are taken from a larger corpus of conversations between clients and officials in various municipal administration offices in North-Rhine-Westfalia, West Germany, mostly a Sozialamt and a Bürgerberatung. (For the description of the institutional contexts and the larger corpus, see Selting (1987a).) The sequences considered here deal with so-called local and global conversational problems; here, especially intonational structures, such as different contours on locutionary similar utterances, normal versus extra strong accent, and jumps to a high or a higher global tone level than in surrounding sequences were found to be used as important communicative signals.

Since especially notions such as 'normal' and 'extra strong' accent, and 'normal' versus 'high' or 'higher' global tone levels are extremely relational, as their auditive criteria of categorization are variable and context dependent, criteria for the validation of auditive analyses need to be stated. The criteria underlying categorizations here refer to the functional interpretation of intonation in context. ${ }^{1}$ They are twofold:

(1) One possible criterion is the intuitive functional interpretation of utterances with these properties by lay transcribers. In many cases, lay tran-

1 As formal and functional categories are taken to be interdependent in relations of reflexivity, the circularity of argumentation as it becomes evident here is the methodological correlate to processes of interpretation in natural conversations. 
scribers note down comments like 'astonished', 'emphatic', 'doubtful', 'sceptical', etc. with reference to these utterances. This criterion points to the fact that in transcribing, listeners perceive the difference between these and other utterances fairly accurately and interpret these properties in specific ways. As, however, no special test or other procedure was devised to analyze this sort of relation between formal properties and functional interpretations, this criterion was not used systematically here.

(2) A second criterion is the reconstruction of recipients' interpretation of these properties. Speakers restrict such prosodic marking devices systematically to specific turns in conversational development and thus oppose marked and unmarked intonations as conversational signalling devices. Recipients in general react differently to prosodically unmarked utterances on a normal tone level and with normal accents than to prosodically marked utterances on a high or higher global tone level and with extra strong accents. This points to the fact that recipients perceive the difference between prosodically unmarked and marked utterances fairly accurately, and interpret the respective utterances as activities with different sequential implications. This second criterion is used systematically here to analyze the function of intonation in conversations and to validate auditive analyses of intonations with respect to relational categories.

The analyses presented here are largely based on previous extensive analyses of problem handling sequences in conversations (cf. Selting (1987a, 1987b, 1987c)).

\section{Intonation as a type-distinctive cue in signalling local problems in conversa- tion}

The category of 'local conversational problems' refers to cases in which a recipient signals a problem with respect to prior speaker's last utterance or last turn; the recipient can ascribe this problem to her- or himself or to the other. The sequences dealing with such problems largely correspond to 'otherinitiated self-repair' and 'other-initiated other-repair' in ethnomethodological analysis (cf. Schegloff, Jefferson and Sacks (1977)). By contrast, the analysis of such sequences in the present paper takes the perspectives of the participants into account. 'Other-initiated self-repair' then refers to sequences in which a self-ascribed problem to be treated by the other is manifested by the recipient of the problematic item, whereas 'other-initiated other-repair' refers to sequences in which an other-ascribed problem is manifested and treated by the recipient of the problematic item. (Cf. Selting $(1987 \mathrm{a}, 1987 \mathrm{c})$ for a more extensive discussion of the ethnomethodological analysis of repair sequences and for a more comprehensive analysis of the sequences dealt with here.) 
In signalling a local conversational problem, speakers use intonation as well as syntactic and semantic cues to signal a problem categorization, i.e. their assumption as to which type of problem needs treatment, with each manifestation of a problem type requiring its own conditionally relevant treatment strategy: problems on the level of acoustic decoding or formulating an utterance, problems on the level of semantic organization (relating objects/ expressions to each other or to referents and meanings), or problems on the level of expectations (compatibility of messages or activities with own knowledge and expectations). ${ }^{2}$

\subsection{Signalling of self-ascribed problems}

Question words like was ('what'), wie ('how') or wo ('where') are used as a single element with three different intonations to signal three different types of self-ascribed problems of understanding. Here follow three examples in which was is used: ${ }^{3}$

2 The role of intonation in signalling the relation of repair or problem handling side sequences to the surrounding conversation is not dealt with here. But cf. Goldberg (1979), who analyses shifts in peak amplitude, measured instrumentally, as a means of signalling the affiliation or disaffiliation of utterances to prior utterances. She found that "speakers were found to routinely lower in peak amplitude their repair-type questions relative to their immediately prior question components" (1979: 208). Goldberg does not state explicitly what she takes to count as repair, though, nor does she differentiate between different types of repair.

3 The following transcription conventions are used for text lines:

Intonation and characterization of speech styles:

$x$ Falling intonation Noted at the end of

$x^{\prime} \quad$ Rising intonation a unit, direction from

$x$ - Level intonation $\int$ the last accented syllable of a unit

aber dá kam Primary accented syllable(s) of a unit

sícher Extra strong accent

si:cher Lengthening of a sound

sicher Lengthening of a whole word

sicher Fast tempo of short passages

(ast) * Characterizes way of speaking; end

(quiet) * ${ }^{*} \quad$ indicated by '*'

$\uparrow, \downarrow^{*} \quad$ Pitch jumps to globally higher or lower tone levels until **

Pauses:

. Short pause of ca. 1-2 seconds

.. Pause of ca. 2-4 seconds

... Pause of ca. 5 seconds

$+\ldots+\quad$ Pause between turns which cannot be ascribed to one speaker

Intelligibility:

(..), (...) Unintelligible passage; dots according to length

(? er kommt ?) Uncertain transcription

a(l)so

Sounds not identified with certainty 


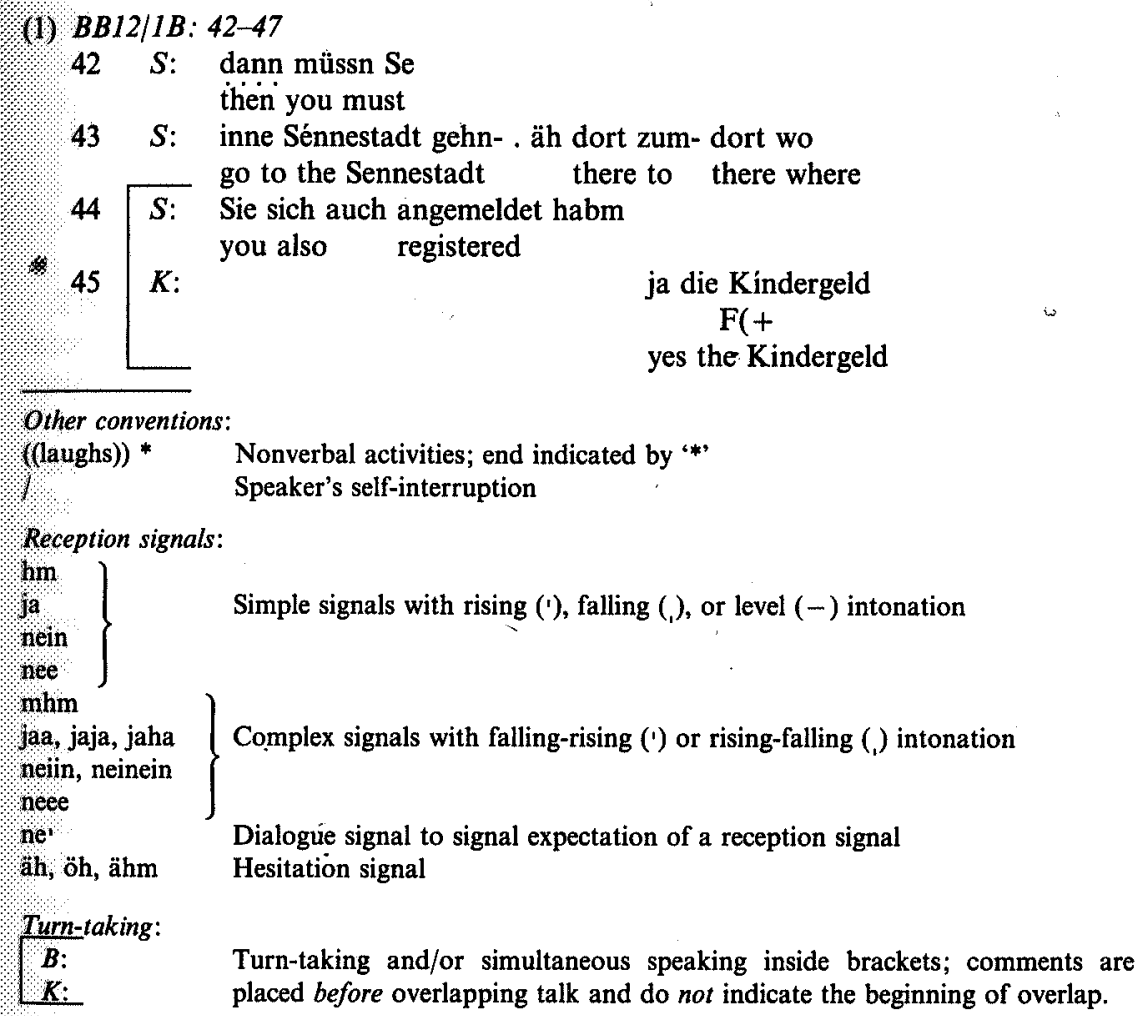

In the intonation lines, the following symbols are used (see Selting (1987d) for a detailed explanation):

Local categories: accent types:

$\begin{array}{ll}+ & \text { Upward 'peak' and/or falling pitch movement of the form ' } \\ \text { Downward 'valley' and/or rising pitch movement of the form ' } \\ \text { Level pitch movement of the form '- } \\ \text { Local upward/downward pitch jumps co-occurring with an accent }\end{array}$

Global categories: cohesive units/contours:

( ) Extent of a sequence of cohesive accents

F/R/H/M/L ( Global direction of pitch of a cohesive unit: Falling, Rising, High, Middle,

(..) $\quad$ Sequence of weakly accented or unaccented syllables

Tails:

\%- Falling, rising and level tails

I am grateful to the Bürgerberatung and to the Institut für Deutsche Sprache, Mannheim, for permission to use the material quoted in this paper. The conversations indicated by 'BB' were recorded in the Bürgerberatung; the conversations indicated by ' $S$ ' were provided by the Institut für Deutsche Sprache: 


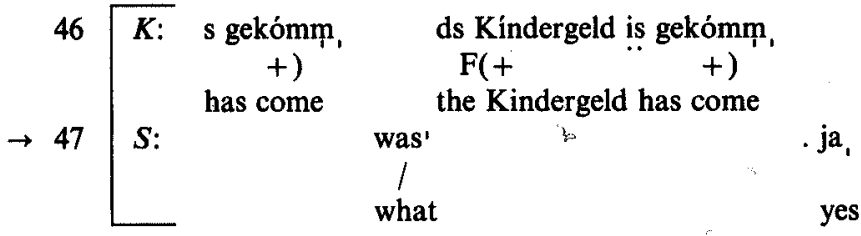

(2) S-34-3: 264-271

$264 S: \quad$.. Wéihnachtsmann, natúrlich hasse letzte Jahr für $\mathrm{n}$ (+) $\quad \mathbf{F}(+$

Santa Claus of course you have last year for the

$2 6 5 \longdiv { S : }$ Jungṇ wat jekricht, já, habta do(ch)

boy got something yes but you got

$\rightarrow 266 \quad \mathrm{~K}: \quad \begin{aligned} & \text { wát denn, } \\ & (+)^{\prime} \\ & \text { what then }\end{aligned}$

$267 S$ : húndertachtzig Márk gekricht, f für Dích néunzig' für

$+\quad+)^{\prime} \quad \mathrm{F}(+-) /$

hundredandeighty marks for you ninety for

$268 S:$ die Brigitte fümenvierzig' und für den Jungn áuch $\mathrm{F}(+-) / \mathbf{R}(++)^{\prime}$ the Brigitte fortyfive and for the boy also

$2 6 9 \longdiv { S : }$ fümuvierzig, sind hundertáchtzig,

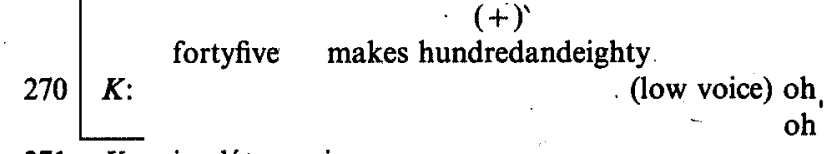

$271 K:$ is dát wenig,

$\mathrm{F}(+++)^{\prime}$

is that little

(3) BB9/2B: 6-12

6 S1: das kóstet allerdíngs- sag ịch Ihn

it costs though I mention it

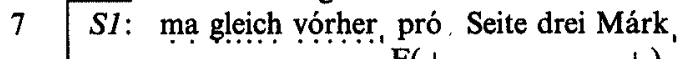
$F(+$
to you beforehand per page three marks

$\rightarrow 8 \quad K 1: \quad \begin{array}{ll}\uparrow w^{\prime} s^{*} \\ \\ \mathrm{H}(-) / / \\ \text { what }\end{array}$

$9 \quad S 1$ : ich múß also jetz- jéde beglaubichte Séite

$$
(+)-F(+
$$

I must then now every attested page

$10 \quad S 1$; nehm ich Ihn drei Mark,

I take of you three marks 
K2: . wieso kostet das denn Géld der bráucht

but why does it cost money he needs

12. K2: das doch für ne . Bewérbung, $+)^{\prime}$

it for an

application

The question word was in extract (1) is only weakly accented and has rising intonation. It is used to signal a problem of acoustic decoding and the recipient accordingly reacts with a repetition of the problematic turn.

In extract (2), the same question word was is used in its dialect variant wat, here in combination with the particle denn, which could very well be omitted. The question has normal accent and falling intonation. In other examples, wie, wó, etc. are used as single elements with a similar function. In contrast to the use of elements with rising intonation to signal a speaker's problem of acoustic decoding of a prior turn, elements with falling intonation signal a referential problem, viz. the speaker is unable to identify the referent of a referring expression (cf. Thrane $(1980: 41)$ ) in the preceding utterance and wants the previous speaker to substitute or add another referring expression for, respectively to, the original problematic one. The mere substitution or addition of another referring expression as a device to treat this problem type indicates that both interlocutors believe that the problem is only a momentary one; there is no need to give any background information or to explain the meaning of the problematic item. In extract (2), the question word wát refers back to the pronoun wat ('something'), used by $S$ as a referring expression referring to a certain, unspecified amount of money in line 265: $K$ presumably does not know what money $S$ refers to. $S$ treats this problem by giving the exact amount of money paid to $K$ s family, a specific numeral replacing the original wat.

In extract (3), the question word was in line 8 is realized on a high tone level and with an extra strong accent. This intonational marking differentiates it from the use of the same element to signal a problem of acoustic decoding. This realization of the question word functions to signal a problem of expectation: $K l$ has understood the previous utterance acoustically and he can interpret its meaning, but he has not expected that he has to pay three marks per page to have his school report officially attested. This problem, however, is not treated by $S 1$ in the expected way, e.g. by an attempt to clarify the contradiction between Sl's knowledge of official regulations concerning attestations and the clients' expectations. Therefore, $K 2$ manifests the clients' problem of expectation again in lines 11-12 in a more explicit form and thus confirms the interpretation of the first prosodically marked utterance in line 8 as a first problem manifestation for this problem type. (On the preference structures interfering here, see Selting (1987a, 1987b).) 
The same lexical items, viz. question words such as was, wie, wo, etc., either in isolation or (sometimes) with a particle, are thus used with three different intonations to signal different types of local problems of understanding, requiring different types of problem treatment:

- A question word like e.g. was' with (-)/ or / intonation signals a problem of acoustic decoding.

- A question word like was with $(+)$ ' or ' intonation signals a referential problem.

- A prosodically marked question word like e.g. \wás' with extra.strong accents and/or high global tone level (but never unaccented) signals a problem of expectation.

In cases where a single question word is used to signal a local problem of understanding, intonation is the only type-distinguishing cue. The question words wieso, weshalb, warum (all meaning 'why'), however, are not differentiated in this way. They are only used in combination with an explicit anaphorical reference to the problematic item, as an alternative manifestation to the prosodically marked question words to signal problems of expectation.

In order to differentiate the signalling of problems of acoustic decoding, reference, and expectation from signalling problems of understanding the meaning of an expression, syntactic cues are used. In contrast to the isolated use of question words in the examples given above, a repetition or an anaphorical element explicitly referring back to the problematic item is used to manifest a problem with interpreting its meaning. Thus, either a question word such as wie, wo, wat fürn ('how', 'where', 'which') plus a repetition or an anaphorical element with falling intonation as in

"wie alles weg jetz," ("how everything gone now,")

"wó istn das," ("where is that,")

or the mere repetition of the problematic item with rising intonation in a socalled echo-question like

"MéBtischblätter"" ("measuring table sheets'")

are used to signal that the speaker cannot interpret the meaning of the item explicitly indicated and wants the recipient to provide additional information, such as an explanation of the meaning of the word or the function of the object referred to, or other background information. This additional information is often introduced with indefinite expressions. For reasons of space, I shall not go into more detail (but cf. Selting (1987a)). 


\section{Signalling of other-ascribed problems}

In the performance of other-corrections as manifestations of other-ascribed problems, it is also intonation and syntax which are apparently used as cues to signal the type of problem:

(4) $B B 3 / 8 B: 13-23$

13 S1: .. a(l)so Stádtplan

so a city map

14 SI: reicht nich, doesn't do bíßchen grổßer, . a bit larger

$K: \quad$ bißchen gróßer a bit larger

$1 6 \longdiv { S 1 : }$ es gibt son-sonthere is a ' $a$

one to twentyfive thousand

$18 K$ : oder so, or so

S1: . (low voice) eins zu zwánzigtausend, já *

$$
\begin{aligned}
& \mathrm{M}(. .+)^{\prime} \\
& \text { one to twentythousand isn't it }
\end{aligned}
$$

$20 \quad K$ : eins zu z/zwánzigtausend hat der, one to twentythousand it is

$22 S$ : : is der- . jetz gibt es noch $n$ grốßeren- der hängtit is now there is an even larger one it hangs

23 S1: der hängt hier vorne auf dem Flúr, it hangs here right on the corridor

(5) S-31-6: 149-157

149 B: aber der A hat uns ja áuch

but the $A$ has. us too

$150 \quad B:$ erzählt daß Sie- äh- (each word articulated separately) told that you

151. B: in der Wírtschaft Écke Póstweg und-* Erzbergerstraße in the pub on the corner Postweg and Erzbergerstraße

$B$ : häufig sind, . ja ich wéiß often are yes I know

$K$ : $\quad \uparrow$ Érzbergerstraße (breathy) is das, ${ }^{*}$ $\mathrm{H}(+)$

Erzbergerstraße is that 


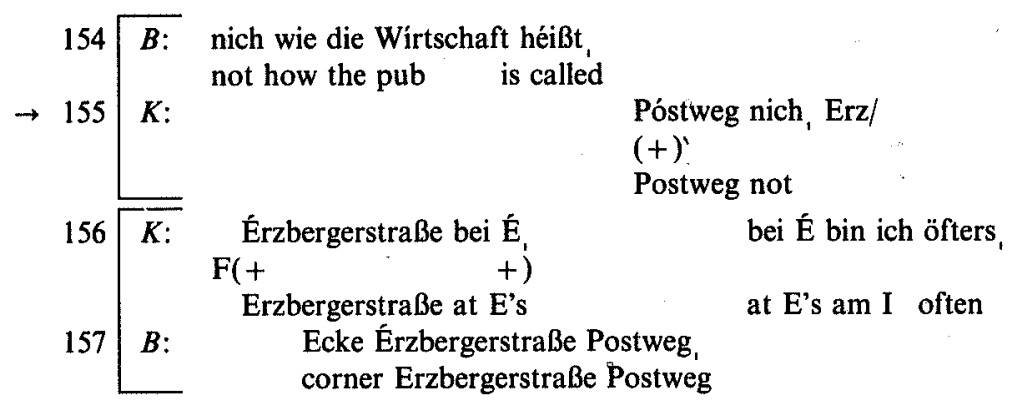

(6) $S-33-4: 249-259$

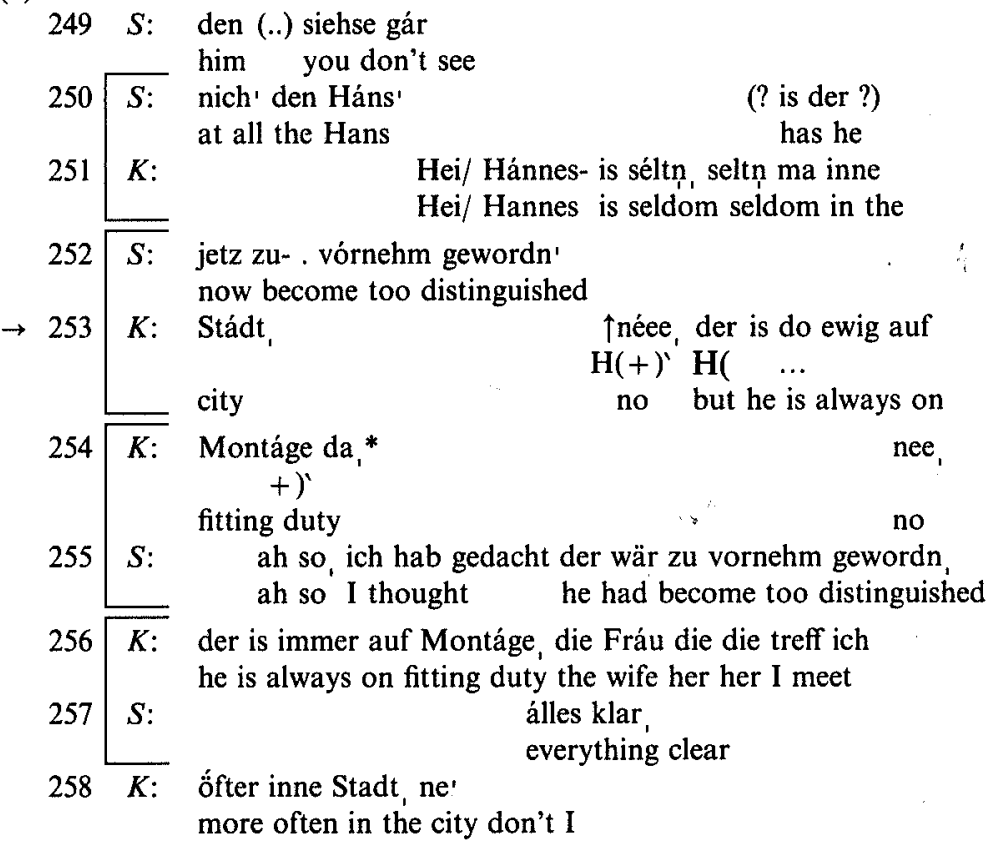

In extract (4), the other-correction in line 19 is done in a low voice and with a normal accent. There is no introductory element like nein ('no') or $X$ nicht (' $X$ not'); instead the speaker signals with the dialogue signal $j a{ }^{\prime}$ at the end of the correction that he expects the recipient to accept his correction. The correction is done in an unmarked and subdued way. The corrector seems to suppose there is only a momentary problem of formulation: The speaker has messed up his wording, and he is assumed, in principle, to know the correct word for the referent in question.

In extract (5), two different, marked corrections are produced by $K$ in lines 153 and $155-156$ respectively. The first one is marked by its realization on a 
high global tone level; the second one is marked by the use of the explicit rejection Póstweg nich to introduce the correction. Both forms of marked other-corrections are used as alternatives in my data to identify the same type of problem, viz. the correction of a supposed error in relating expressions and their denotata, or in relating objects to other objects. For this type of problem, the corrector uses a rejection plus a subsequent, prosodically marked or unmarked correction; alternatively (if no introductory element is used), a correction with an obligatory prosodical marker (higher global tone level or stronger accents).

The same sort of alternative marking cues is used in a third type of othercorrection, which is differentiated by its syntactically 'well formed' finite sentence structure' from the corrections in (4) and (5) where only a single item was replaced. This third type of other-correction is illustrated in extract (6), where the correction in lines $253-254$ has an introductory rejection and is realized on a high global tone level. With this type of other-correction, realized in a syntactically 'well formed sentence' - with an obligatory prosodical marker if it is not preceded by an introductory element, and with an optional prosodical marker if it is preceded by an introductory element - a problem of expectation or inferencing is indicated. In extract (6), $K$ rejects $S$ 's expectation or inference that the man called "Hans" or "Hannes" and $K$ rarely meet because of Hannes' having become too high and mighty, and offers the alternative explanation that they rarely meet because of Hannes' new job.

In signalling other-ascribed problems, it is thus the alternation of intonational and syntactic cues which functions as type-distinguishing cues:

- Replacement of a single element of the preceding utterance without introductory element and without intonational marking signals a problem of formulation.

- Replacement of a single element of the preceding utterance, either with introductory rejection plus optional intonational marking of the correction proper, or without introductory rejection but with obligatory intonational marking of the correction proper, signals a supposed error in relating expressions and/or objects.

- Replacement of an utterance by a syntactically well formed alternative utterance, either with introductory rejection plus optional intonational marking of the correction proper, or without introductory rejection but with obligatory intonational marking of the correction proper, signals a problem of expectation or inferencing.

Thus, both with self- and with other-ascribed problems, intonation (either alone or in co-occurrence with syntactic structures) is used to signal the specific type of problem, and trigger a particular problem handling sequence. In some sequences, intonation and syntactic structures are used as alternative 
devices to signal the same type of problem; in other sequences, different intonations with the same syntactic structures, or similar intonations with different syntactic structures are used to distinguish problem types. Both types of sequences point at the interdependence of locutionary and intonational devices. Thus, the function of intonation is a result of the use of a particular intonation in a particular utterance type with a particular syntactic structure in a particular turn in conversation which has a particular relation to the preceding turn. It is, therefore, the co-occurrence of specific forms and structural positions which signals and constitutes the interactive meaning or status of an utterance, not intonation only.

Co-occurrences of this kind are also relevant when intonation is used as a signalling cue in the treatment of a global problem of understanding, as will be shown in the next section.

\section{Intonation as a signalling cue in the treatment of a global problem of understanding}

The role of intonation in the organization of longer, mostly monologic, stretches of talk has been the object of several studies. Yule (1980) and Couper-Kuhlen (1983, 1986: ch. XI) describe major and minor 'paratones' which are used as a sort of 'topic' or 'paragraph' intonation respectively, to signal cohesiveness of a stretch of talk. Couper-Kuhlen further demonstrates how different types of combinations of minor paratones, combinations of rising plus falling tones, subordinations or reduplications of tones, constitute major paratones, the hierarchical organization of intonational units being used as means to signal and constitute the hierarchical organization of longer stretches of talk, such as radio broadcasts, contributions to platform discussions, etc. These paratones seem to be used within turns to signal the internal structure of a speaker's contribution; alternatively, they may transcend turns, when different speakers cooperate in producing topical talk, and signal this by constituting a common paratone structure. Similar hierarchical organizations result from the recursion or iteration of lower level structures constituting higher level structures of intonation; such structures indicating semantic structures of discourses contributions are described by Gibbon (1984).

The above-mentioned studies were primarily concerned with the use of intonation to signal the internal organization and boundaries of topic-centered talk. Intonation was analyzed as contributing to the cohesiveness of texts or discourse sequences. The situational contexts considered are rather formal ones, though. Radio news broadcasts are in general read off from written texts, and contributions to podium discussions are also highly preplanned, rather monological types of discourse. In both cases, the speaking is 
public, speakers addressing a heterogeneous audience and not individual recipients.

Much less is known about the use of intonation in informal conversations, 0.g. to signal and constitute patterns of speaker-recipient cooperation and reciprocity and to control conversation development. Gibbon and Selting (1983) show how the differential use of three different intonation contours by the moderator of a German radio programme (in speech addressed to different addressees) was used as a device to signal different aspects of thematic development and to establish different patterns of reciprocity with the addressees.

In the following, I shall present a conversation in which intonation plays an important organizational role. A client has a global problem of understanding the way in which an official handles his request, as he had expected a different treatment. The intonational cues in question are global ones: The systematic opposition between normal versus high global tone level in the reformulation of arguments at successive stages of the developing conversation, and the type of local accent types used by the official $(S)$ to mark off global contours at different points in his treatment of the problem. The analysis corroborates the hypothesis put forward in Selting (1987d), namely that local and global categories are functionally differentiated in conversations.

Although I will concentrate as far as possible on the role of intonation in the reformulations as indicated in the margin of the transcript, the conversation has to be considered here in its entirety. (For ease of understanding, the conversation is paraphrased.)

\section{$B B 7 / 4 B$ : Change of address}

$K$ has come to the Bürgerberatung ('Citizens' Counseling') in order to have his address changed on an informative statement about his old-age pension, which is sent to him monthly by the federal old-age insurance board. Apparently, he has already been in the Bürgerberatung before for a similar or the same reason and a colleague of $S$ s has already changed the address once before. This time, however, $S$ informs him that the Bürgerberatung is not the institution in charge, as his changing of the address would not result in the note being permanently sent to $K$ s new address. Instead, $K$ is instructed to send a note to the federal old-age insurance board to have his address changed in the computer there. $K$ does not understand this, presumably because $S$ s colleague, whose helpfulness and friendliness $K$ repeatedly hints at, has treated him differently. $S$ handles this global problem of understanding by explaining that the sender of the information is the appropriate address to notify his new address to, because they have $K$ s address in the computer and $S$ s changing of $K$ 's address would not cause a permanent change. This explanation of the appropriate address to write to, and the arguments to back this up are reformulated nine times in the course of the conversation. (As to the term 'reformulation', in this case used for a self-paraphrase of the same original formulation, see Gülich and Kotschi (1985) for a more comprehensive discussion.) 


\section{Transcript}
$1 \longdiv { K }$ : nee- . nee ich suche ein Frẳulein hier, $(=) \quad F(+\quad+)^{\prime}$
no no I am looking for a young lady here
$S: \quad$ Frau XX'
$F(++-))$
Mrs. XX
ja pássen Se ma auf, . ich hab hier ne

$\begin{array}{cc}\mathrm{F}(+ & \mathrm{F}(+ \\ \text { yes pay attention } & \mathrm{I} \text { have here a }\end{array}$
K: Kléinigkeit, . (? lasse ma ?), (..) das fällt immer

$$
+)^{\prime}
$$
trifle matter let it
$S:$
mhm'
$7 \longdiv { K }$ : rúnter, na gébm Se man her, ách lassn Se ma, . dá $+\quad \mathrm{F}(+\quad+) \mathrm{F}(++\quad+$ down well give it to me oh let it there oh,
$9 K: \quad$ isser ja .. ich war néulich schon mal híer-. und
it is
... ) $\mathbf{R}(+$

$10 K: \quad$ ich bráuche- . ne Ânderung- .. pássen Se auf, . ich $\begin{array}{llll} & -) & (\uparrow+)- & (+)^{\prime} \\ 11 & \text { I need } & \text { an alteration } & \text { pay attention I } \\ \text { bin vorges Jahr úmgezogen' } & \text {..(has presum }\end{array}$$$
\mathrm{R}(++-)
$$ have last year moved

$13 K$ : das is noch die álte Adrésse, .
$\mathbf{R}(+\quad+\quad+)^{\prime}$
that is still the old address

$14 K$ : meine néue Adrésse das ist- . díese, . ŹZZstraße, .

$$
\begin{array}{ll}
\mathbf{R}(-\underset{+}{+}+ & \uparrow+)^{\prime}(\uparrow+)^{\prime} \\
\text { my new address that is this one ZZZstraße }
\end{array}
$$

$15 K$ : $\uparrow$ könn Se mir das nich mal ắndern' in-* . (? Ihrm Búch ?),
$\mathrm{H}(-$ 
$16 K:$. dann hättn Se das- , mit dúrchschlagen' . und

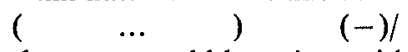

then you would have it with cancelling and

17. $K$ : éinfach ŹZZstraße drunter schreibm' . is das Frắulein
$F(+$ $-) /$ $\mathbf{F}(+\quad-) /$
$1 8 \longdiv { K : }$ da' simply ZZZstraße underneath write is the young lady
23 S: is klár, nur das müssen Se doch dem dem Póstscheckamt (+) $\mathrm{M}(+\quad+$ that's clear but that you must the the postal cheque bureau
$24 S:$ mitteiln' denn sons kommt das doch immer wieder zur

$$
+-) / \mathbf{R}(\ldots+\quad+\quad \ldots \quad+)
$$
tell since otherwise it comes always again to the
$2 5 \longdiv { S : }$ Ystraße,
$K: \quad$ jaa ich kann das hier únt e- . Sie kốnn das

$$
\begin{array}{ll}
(+) \quad \mathrm{M}(+ & \mathbf{R}(- \\
\text { yes I can that here und/ } & \text { you can that }
\end{array}
$$

S's problem manifestation

$27 K$ : hier unterschréibm hier, .. is das Frắulein nicht'

$$
\text { here sign }+)^{\prime} \text { here is the young lady not }
$$

$28 K$ : jch war doch vórges Jahr- vor einiger Zéit ma hier

$$
\mathrm{M}(\ldots+\mathbf{M}(+
$$
I was last year some time ago already here
$2 9 \longdiv { K }$ : da war son Frắulein hier,$$
+)^{\prime \prime}
$$$$
\text { there was a young lady here }
$$ 
$31\left[\begin{array}{cccc}S: & \text { úmgemeldet, } & \multicolumn{2}{c}{\text { jáa }} \\ & +)^{\prime} & (+)^{\prime} \\ & \text { registered anew } & \multicolumn{2}{c}{\text { yes }} \\ & & \text { vorges Jáhr schon } & \text { ja } \\ & & (+)^{\prime} & (+) \\ & & \text { last year already } & \text { yes }\end{array}\right.$

$33 S: \uparrow$ ja aber Sie mússens doch der Búndespost mitteiln, das

$$
\mathrm{H} / \mathrm{R}(++)^{\prime}
$$

yes but you must that the federal post office tell that

$34 S: \quad$ is doch jetz irgendwie: ne Sache die láufend kommt,

$$
\mathrm{H}(+\quad \cdots \quad+)^{\prime}
$$

is after all somehow a thing that comes permanently

35 S: né' ne ne Pos/Póstcheckkontoauszug oder irgend so

$(-) \quad(+)^{\prime}$

isn't it a a pos/ postal cheque account statement or

K: (short)ja, ja ${ }^{*}$

yes yes
$3 7 \longdiv { S : }$ was,
something
dann $\uparrow$ müssen Se den das schréibm,
$\mathrm{H} / \mathrm{R}\left(+\ldots+\frac{+}{+}\right.$
38 K: $\quad$ och,

reformulation 2

reformulation 1

$39 S: \quad$ sons kommt das immer wieder an diese Adresse, . die
$\mathrm{H} / \mathrm{R}(+$
$++)^{\prime}$
otherwise that comes always again to this address they
40
$S: \quad$ ham das doch in ihrm Compúter,
$\mathbf{H} / \mathbf{R}(+$
$+)$

$$
\mathrm{H}(+)-
$$
$\uparrow$ die drückn/
have that after all in their computer
they print
that is

$4 2 \longdiv { S : }$ die drúckṇ das doch automátisch aus, . $\uparrow$ Sie mǘssn

$$
\mathrm{H} / \mathrm{R}(+++)^{\prime} \mathrm{H}(+
$$

they print that automatically you must

$43 \quad K$ : im Com/*. so- só is das, . só is das'

$$
\left.\mathrm{F}(++)^{\prime} \quad \mathrm{M}(+-)\right)
$$

in the com/so so is that so is that

$4 4 \longdiv { S : }$ den das kurz mítteiln' daß Sie also úmgezogen sind' und

$$
-) / \quad(-) /
$$

them that briefly tell that you have moved and 


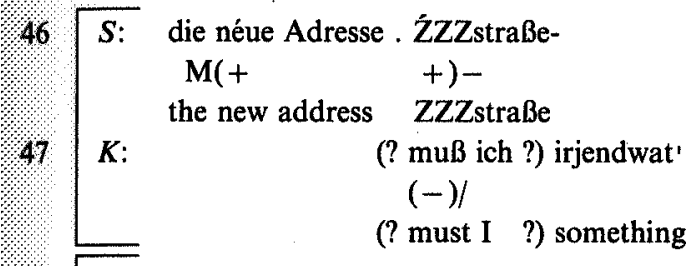

$S:$, bitte'

beg your pardon

$$
\begin{array}{cc}
\uparrow \& \text { néiin, } \uparrow \text { dá ham- } \\
\mathrm{H}(+) & \mathrm{H}(-\quad+) \\
\text { no } & \text { there have }
\end{array}
$$

$49 \quad K: \quad$ (? an dies Ámt, ?). híer àum Ạmt,

$$
F(--) \quad F(+\quad-)
$$

(? to this office?) here at this office

$50 \quad S: \quad$ úmgemeldet hattn Sie sich doch, ne' $\uparrow$ nein, das

$$
\mathrm{H}(-\mathrm{C}+)^{\prime} \quad / \quad(+)
$$

reformulation 4

anew registered you had hadn't you no that

$51 . K$

$$
\begin{gathered}
\text { jaja, } \\
(+)^{\prime}
\end{gathered}
$$

yesyes

$52 \quad S: \quad$ müssen Sie dem dem Empfắnger-* .. mittei- äh dem dem

$$
\mathrm{H}(+\quad \uparrow+) \quad \mathrm{M}(+)-
$$

$$
\text { must you the the addressee }
$$

$5 4 \longdiv { S : }$ Ábsender mitteiln,

$(+)$

sender tell

da bin ich doch néulich hier

$$
\begin{aligned}
& \mathbf{R}(\ldots \\
& \text { but I have recently }
\end{aligned}
$$

$K$ : gewesen da war $\mathrm{n}$ Frấulein hier, . (.) mal wiederkomm,

$$
+)
$$

been there was a young lady here

$$
\text { jaa, Frau X́ vielleicht, }
$$$$
\text { (t) (+) }
$$$$
\text { yes Mrs. X maybe }
$$

$5 8 \longdiv { K : }$. sehn Se, und das háb ich hier úmgeändert gehabt,

$$
\text { R(- + }+)^{\prime}
$$

look and that have I here altered had 


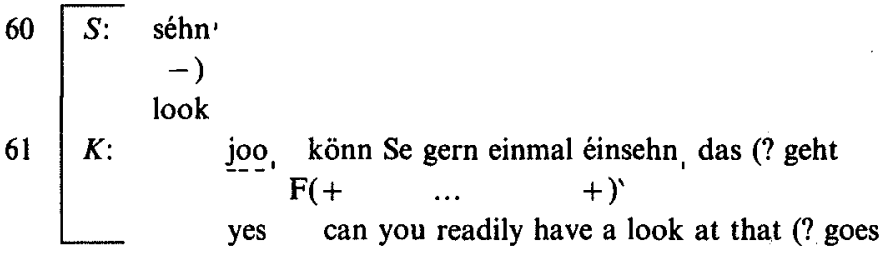

$62 K$ : híer so $\mathrm{ab}$, ?) .. séhn Se híer, . da ist es úmgeändert

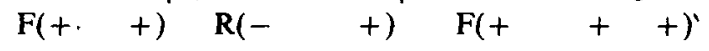

here off like that?) look here there has it been

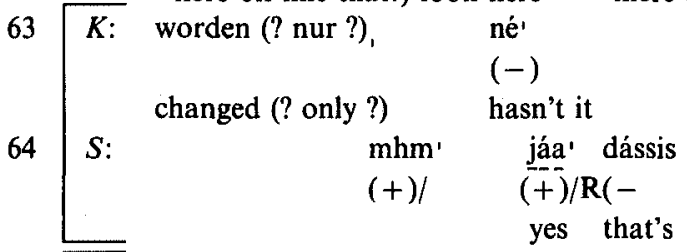

$6 5 \longdiv { S : }$ ríchtig, - †aber Sie müssen dem Ábsender dieser-*.

$+)^{\prime} \quad \mathrm{H}($... $\quad+\quad+)$

right but you must to the sender of this

$66 K$ :

(short) $\quad \mathrm{ja}^{*}$
$/$
yes

reformulation

$67 S:$ das \$/ das șind: Réntenbescheide oder irgendwas ne'

$$
\mathrm{F}(+\quad \cdots, 1
$$

that's that are pension informations or so aren't they

$6 8 \longdiv { S : }$. s. kommt régelmäßig, né . †dás

$$
\mathrm{F}(\cdots+)^{\prime} \quad(-) \mathrm{H} / \mathrm{F}(+
$$

it comes regularly aren't they that

69

K:

- só is das so,

$$
\mathrm{F}(++)^{\prime}
$$

so it is so

$70 \quad S:$ müssen Sie n mitteiln,

$$
+)^{\prime \prime} \quad \mathrm{H}(+
$$

must you to them tell you must

$7 1 \longdiv { S : }$ also den schréibm . daß Sie úmgezogn sind- und äh daß

$\begin{array}{ccc}\ldots & + & + \\ \text { then to them write that you have moved } & - & \text { and }\end{array}$

$72 K$ : dann múß dat nach Hannóver schreibm'

$$
\mathbf{R}(+\quad+\quad-) /
$$

then must that to Hannover write

$73 \quad S$ : Ihre néue Adresse jetz ZZZstraße* nochwas-lautet,

$$
+\quad+\quad \downarrow+)^{\prime}
$$

your new address now ZZZstraße something is 
74 $\bar{K}$ dann múB ich das nach Hannóver schreibm.

$$
\mathbf{R}(+\quad \ldots+\quad+)^{\prime}
$$

problem solution

then must I that to Hannover write

jahá' .

$$
(-)
$$$$
\text { yes }
$$

76 S: $\uparrow$ denn sonst kommt das immer wieder

$$
\mathrm{H} / \mathbf{R}(+++)^{\prime}
$$

since otherwise comes it always again

$77 \sqrt{S:}$ falsch, das wird ja áutomátisch gedrúckt ${ }^{*}$ *

$$
\mathrm{H}(\ldots++-)^{-}
$$

wrong that is being automatically printed

$K$ :

ich dáchte

$$
\mathbf{M}(+
$$

I thought

$79 \quad K$ : wohl Sie könnten híer- . die: die neue Adrésse

$$
+\mathbf{R}(-
$$

you could here the the new address

$8 0 \longdiv { K : }$ draufmachen,

$$
+)^{\prime}
$$

fix on it

$S:$

.. ja aes nǘtzt ja nichts, denn kómmt der

$$
\mathbf{F}(+\ldots) \quad \mathbf{M}(+
$$

yes but it's no use then comes the

82

$S:$ nắchste wieder falsch,<smiles>[131IH]</smiles>

next one again wrong

so es kommt wíeder, najá

$$
\begin{array}{ll}
\mathbf{R}(\ldots & +\ldots \\
\text { so it comes again } & \text { okey then }
\end{array}
$$

$84 K:$ dann- . dánn machen wa s ánders, . (very quiet) naja,

$$
\text { .. ) } \mathbf{F}(+\quad+)^{\prime}
$$

then then do we it differently né'

doesn't it reformulation 7 problem solution implied

$85 \quad K: \quad(.)^{*} \ldots$ (quiet) $\downarrow$ hab ich noch Lást damit, ..

$86\left[\begin{array}{ll}K: & \mathrm{t} \text { Klǘngeléi }{ }_{1}^{*} \\ \mathrm{~L} / \mathrm{F}(++)\end{array}\right.$

$$
\mathrm{L}\left(\begin{array}{ll}
\text {... } & +)^{\prime}
\end{array}\right.
$$

have I got the burden with it

whole bunch

$S: \quad$ (to colleague) ham wir nich so: so Kártn

$$
\begin{array}{lr}
\mathrm{F}(+ & -) / \\
\text { have we not so } & \text { so cards }
\end{array}
$$




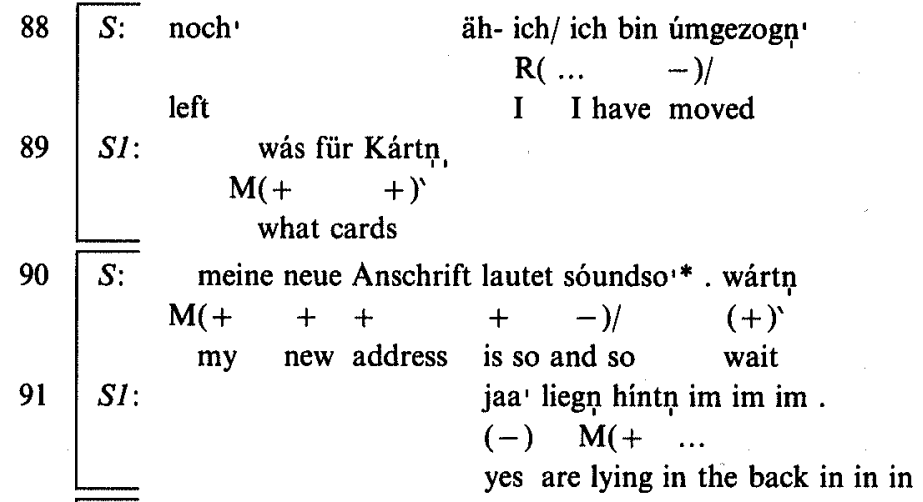

$9 2 \longdiv { S : }$ Se ma, ich géb Ihn mal son paar $\mathbf{R}(+$ I give you just a few

S1: Regál, wenn Se: wenn Se vor dem $+\quad \mathbf{R}(\quad \ldots$

the shelves if you if you in front of the

$9 4 \longdiv { S : }$ Kártn, *

$\uparrow+)^{\prime}$ cards

95. S1: †réchtṇ stehn auf der rechtṇ Séite,..++ $+\ldots+\quad+=$ )

right one stand on the right side

$96 K$ : ((short moaning)) ... (quietly, as if to himself) da múB

$97 K$ : ich das ja nach Hannóver schreibm, oh- dassís ja wat, .

$$
+)(+)^{\prime}
$$

I that to Hannover write oh that's a thing

$98 K:$ da is auch gar keine Adrésse- (? nu auch ?) keine (quiet)

$$
\begin{gathered}
\mathrm{L}(\ldots \\
\text { there is also no address }
\end{gathered}
$$

$9 9 \longdiv { K : } \begin{array} { r } { \text { Adréss } } \\ { + \text { ) } } \end{array}$

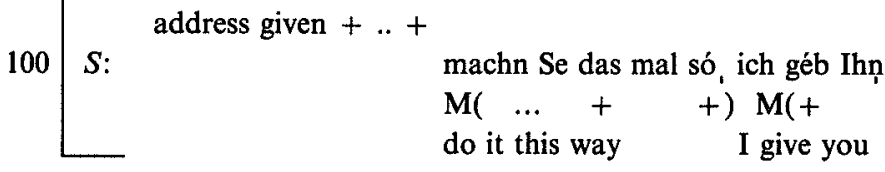




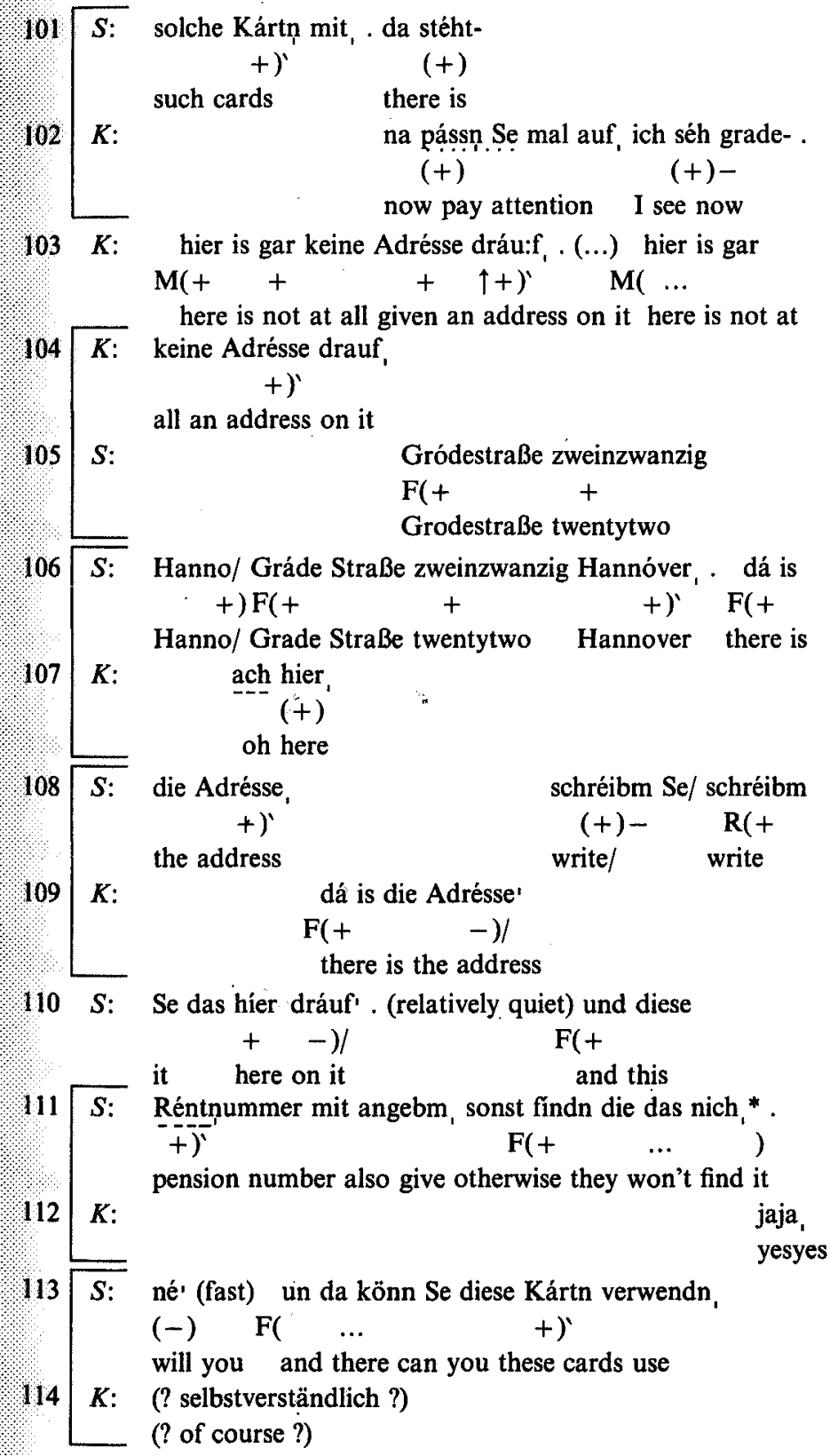




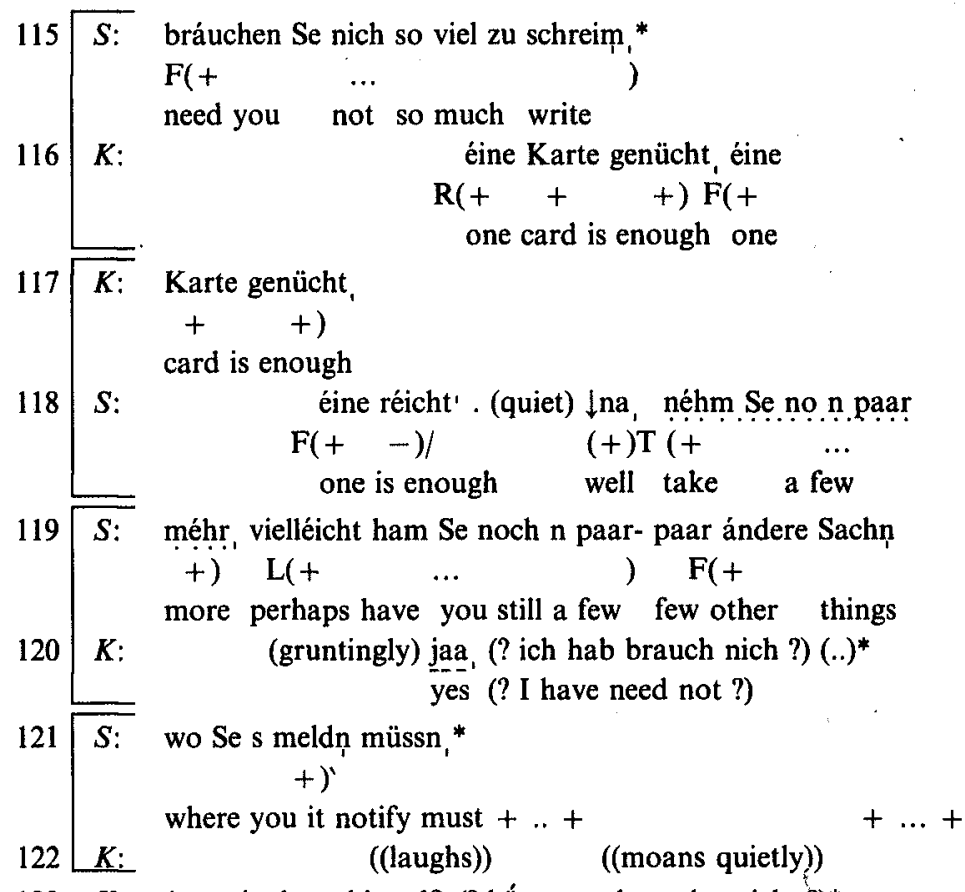

$123 K$ : (gruntingly to himself) (? hắttn wa dann das nich, ?)* $+\ldots+$ $(+)$

(? had we then that not?)

$124 K$ : sind die ja ganz ferti d fértig die Kartṇ, ... né'
$\mathrm{M}(+$
$+)^{\prime}$

are they then all done $d$ done the cards aren't they

S: (short) bídde'

$(-)$

pardon

$K: \quad$ (a bit slower, more clearly) ich sach die sínd

$$
\begin{array}{rll}
\mathbf{R}( & \ldots & + \\
\text { I } & \text { say } & \text { they are }
\end{array}
$$

$1 2 7 \longdiv { K : }$ ja schon fértig die Kartñ. ${ }^{*}$

$$
+)^{\prime}
$$

already done the cards

jája, bráuchen Se núr die:

$(+) \mathrm{M}(+\quad+$

yesyes need you only the 

$1 2 9 \longdiv { S : }$ neue Adresse éinzusetzen- únd diese Réntennummer nich$$
++)-\mathrm{F}(\uparrow+\quad+\quad \ldots
$$
new address fill in and this pension number not
130 K: blóß n Nám noch,
$F(+\quad+)^{\prime}$
only the name still
131 $S:$ vergessen, sons findn: (gradually quieter) die das in
forget otherwise they wont't find it in
132
$K$ : jaa, ja- ja, yes
$1 3 3 \longdiv { S : }$ der Rentnversicherungsanstalt nich, ${ }^{*}$ the old age pension insurance office

$135 K$ : das läßt sich híer drauf- . verbúcht werdn

$$
+)-(+)^{\prime}
$$

that could have been on here counted

$1 3 6 \longdiv { S : }$ oder wie oder wat-* ich bin-
or how or what
I am

$137 \mathrm{~S}$ : (quiet) néinein, (louder and immedia- die Úmmeldung

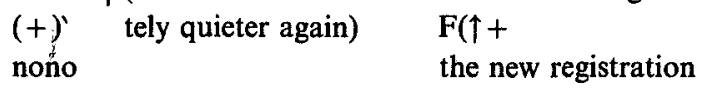

$1 3 8 \longdiv { S : }$ is ja . gemácht wordn, dás is ja klár.

$$
+)^{\prime} \quad \mathrm{F}(-\quad+)
$$

has already been made that is clear

$139 K$ : (quiet) ich war nämlich hier da war son- son Frấulein

$$
\begin{aligned}
& \mathrm{F}(+\quad+\ldots) \quad \mathrm{F}(+ \\
& \text { I was namely here there was such a young lady }
\end{aligned}
$$

$140 \mathrm{~K}$ : hier die hat mir da wohl (? au ?) bisken mit gehólfn,

here she has me with it (? too ?) a bit of help

$141 K: \quad$. (quiet) och . mir egál- . nee das isse nícht, . da ísse

$$
\mathrm{M}(+\quad+) \quad \mathrm{F}(++)^{\prime} \quad(+)^{\prime}
$$

oh it's the same no that isn't her there she

$1 4 2 \longdiv { K : }$ nich, né'*

$$
(-)
$$

isn't is she 
$1 4 4 \longdiv { S : }$ das ebm schréibm, wenn Ihṇ das Múhe machtthat just write if for you it is a burden

(gruntingly) (? néin, ?)*

$1 4 6 \longdiv { S : }$ (relatively quiet) denn dássis kein Problém, ${ }^{*}$

$$
\mathbf{R}(-\quad+)
$$
because that's no problem

$148 K$ K: das Fräulein- , ách nee, ja híer hier hier hier hiẹ hier-*

$$
+)-(+)^{\prime}
$$

the young lady oh no yes here here here here here here ((pause of ca. 10 seconds))

$150 K$ : (quiet) híer *

$$
(+)
$$

here

((pause of ca. 30 seconds))

$152 \quad K$ : séhn Se híer- . dás war das Fräulein das das hier$\mathrm{F}(+\quad+)-(+)-$ look here that was the young lady who this here

$1 5 4 \longdiv { S : } \quad \dot { Z }$, ja die is nur mánchmal da . aber ich kann Ihn

$$
(+)^{\prime} \mathrm{F}(+\quad+)^{\prime} \quad \mathbf{R}(+
$$

$Z$ yes she is only sometimes here but I can for you

$$
\begin{aligned}
& \text { tsó' } \\
& (-)
\end{aligned}
$$

so

$1 5 6 \longdiv { S : }$ das schréibm ebm, das is aso kein Problém, wenn Se das

$$
+)^{n} \quad \mathbf{R}(-\quad \ldots \quad+\text { ) } \mathrm{M}(
$$

that write just that is no problem if you that

ah no

$1 5 8 \longdiv { S : }$ nich selbst machn wolln' né' .

- - ) /

don't want to do yourself

dás ma ích schon, 
$160 \mathrm{~S}$ : brauchen Se núr die Réntennummer mit angebm, (quieter)

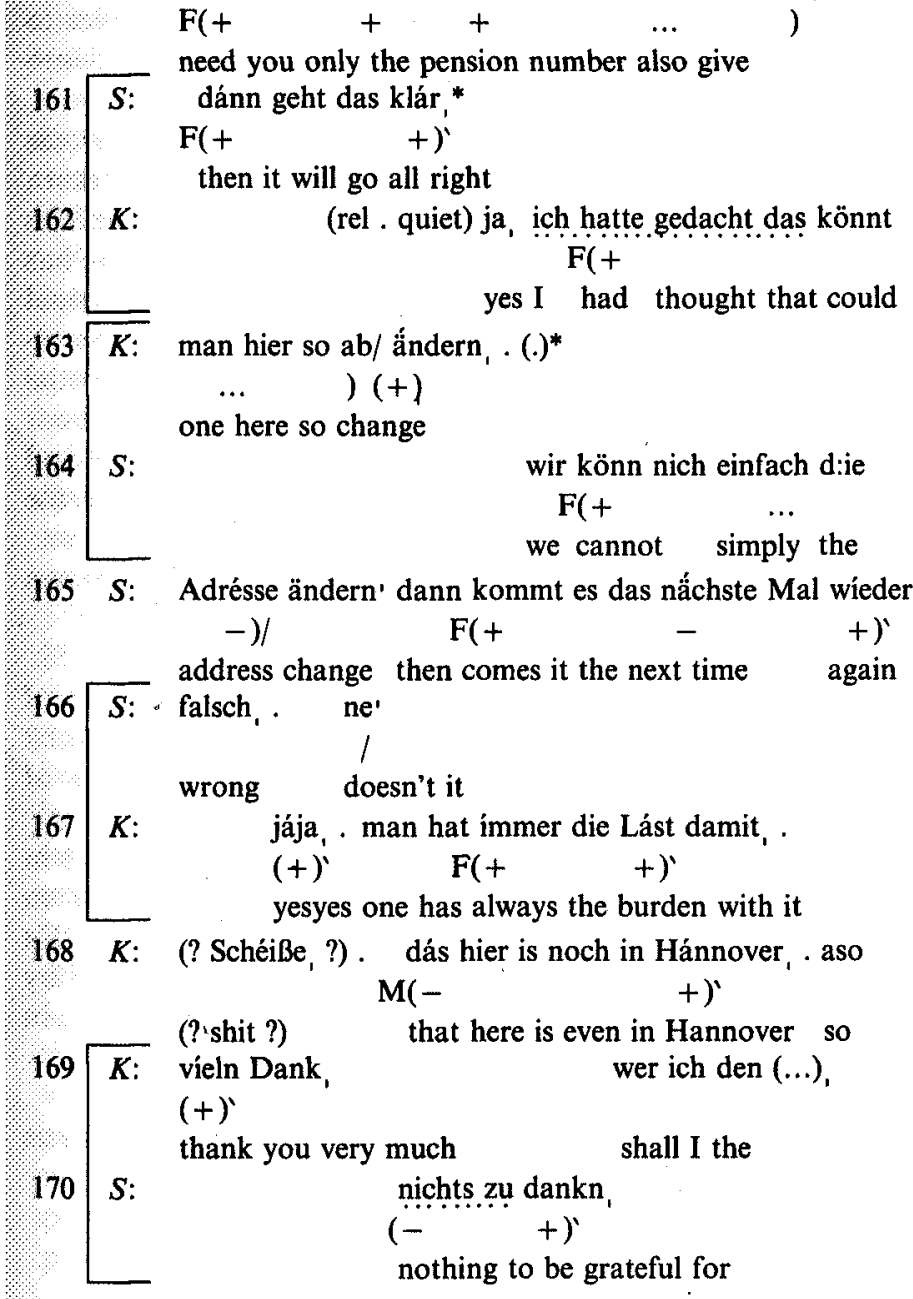

In this conversation, both the use of high global tone level in $S$ 's reformulations as well as $S$ 's use of '-'-accents can be related to the stages of problem handling and to the degree of agreement or convergence between $S$ and $K$.

S's differential use of normal versus high global tone level seems to be directly related to his interpretations of the stages in the treatment of the problem. All of $S$ 's contributions up to line 33, in particular his first original formulation of the solution to $K^{\prime}$ s problem in lines $23-25$, which seems to be a reasonable place to deal with $K$ 's expectations, are formulated on a normal tone level. When $K$ does not accept $S$ 's suggestions, $S$ reformulates the original problem treatment nine times in the course of the conversation. 
Reformulations 1 to 7 are all realized on a high global tone level, whereas reformulations 8 and 9 are realized on a normal tone level again. In order to interpret this functionally, the conversational context has to be taken into account.

Reformulations 1 to 7 are all pre-problem solving activities, whereas reformulations 8 and 9 are post-problem solving activities. Before $S$ 's return to a normal tone level in reformulation $8, K$ had signalled that he has understood $S$ 's suggestions: In lines $72-74$ he stated his inference that he has to write to "Hannóver", and in lines 78-80 he referred to his original expectation in the past tense, thereby possibly signalling a change of expectation and thus of his attitude to solving the problem. Whereas the sequential implications of problem treatment in reformulations 1 to 7 are to bring about a solution to the problem, the sequential implication of reformulations 8 and 9 is a different one, namely to retrospectively ratify $S$ 's handling of the problem.

Jumps from normal to high global tone level in $S$ 's reformulation turns can thus be interpreted as follows:

- They seem to signal the status of an utterance/turn as the reformulation of a prior utterance/turn within the activities of problem treatment, in contrast to the return to normal tone level afterwards, signalling the status of reformulations as post-problem solving activity.

- Interactively, these jumps and further uses of high level tone intonations in the reformulations seem to reinforce the obligation for the recipient to respond in the way expected by the speaker, i.e. here to accept $S$ ss suggestions and get done with the problem. This hypothesis is validated by the fact that after $K$ 's signal of acceptance, normal tone level is used again by $S .{ }^{4}$

Retrospectively, this internal systematicity of the conversation can be taken as a validation of the auditive analysis of tone levels, too.

4 Co-occurrences of features on several descriptive levels also seem to be involved, for instance, in dictating a text to a secretary; digressions or instructions, as elements not belonging to the actual text, are set apart from the text by using low level intonation. The same appears to be the case in some other side-sequences in conversations. Switches to low level intonation thus contribute to the constitution of certain side sequences and digressions. The respective utterances are presumably signalled as less important or less central than the surrounding talk, and sometimes the speaker seems to signal to the recipient that she/he need not respond to this part of his turn. In contrast, jumps to high level tone (as used in the examples above) seem to signal reinforcement of obligations such as the fulfilment of conditionally relevant activities; in this function, they are also used in uptake securing devices (cf. Selting 1985). French and Local (1983) analyze raised pitch as one feature involved in the management and signalling of simultaneous speech by two speakers as competitive with respect to turn holding and turn yielding. 
1n contrast to these more global functions of high global tone level in conversational development, $S$ 's varying use of different accent types and the local modifications of accents to establish intonation contours seem to be more directly related to $S$ 's inferences about the nature of reciprocity and the distance separating the partners from a solution at different stages of the treatment.

K predominantly uses contours consisting of combinations of ' + '- and 2. accents; his speech style is heard as a sort of smooth upward and downward movement of pitch which is used throughout the conversation. $S$, however, alternates between contours like the ones $K$ uses and contours solely combining ' +'-accents. As the choice of contour in $S$ 's speech style seems to be related to his inferences about the distance still to be travelled towards a solution of the problem, and to his respective attempts to control the further development of the conversation, this systematic use of intonation contours seems to be similar to the signalling of convergence versus divergence of speech styles (cf. Thakerar, Giles and Cheshire (1982); Selting (1985)).

Thus, in the first formulation to treat. $K$ 's problem of expectation in lines $2325, S$ uses a '- '-accent in line 24 , thereby using the same sort of contour that $K$ used before. In reformulation 1 , in contrast, all accents are '+'-accents, except for the separate 'pursuit-of-response'-signal (cf. Jefferson (1981)) né' in line 35. My impression that $S$ here is separating his intonation from that used by $K$ is further reinforced by the immediately following utterances where $S$ reformulates his original wording for the second time in lines 37-42. In this reformulation 2 (like the preceding one formulated on a high global tone level), again only ' + '-accents are used. Additionally, some items carry extra strong accents and thus seem to emphasize elements which are in contrast to $K$ s expectations. $S$ seems to move his intonation even further away here from the non-emphatic speech style hitherto used by $K$ and himself; their different views seem to be highlighted here. In a similar way, in reformulations 4,5 , and 6, only it '-accents are used. All these reformulations follow turns in which $K$ signalled that he either did not understand or does not accept $S$ 's previous treatment of the problem. $S$ here has to infer that the solution to the problem is still far away.

On the other hand, in the original formulation, as well as in reformulations $3,7,8$, and 9 , and in the sequences concerned with the background of the problem rather than directly with the problematic issue (lines 55-65), - -'-accents are used again. All these reformulations follow turns in which $K$ seemed to be about to accept $S$ 's handling of the problem (cf. $K$ 's contributions in lines 43,72 , and 74 ), or in which a problem solution was actually signalled (cf. lines 78-80, following which $S$ also resumes normal global tone level again). On the verge to an expected and/or signalled problem solution in lines 72 and 74, where $K$ at first tentatively and then definitely states his inference that he has to write to Hannover, $S$ in his reformulation 7 still uses 
high level tone intonation, but ends in a '- '-accent. In addition, instead of the particle doch which was used in former reformulations to urge $K$ to accept $S$ 's suggestions, in reformulation $7 S$ uses the particle $j a$ to refer to an achieved consensus.

The differential use of ' - '-accents by $S$ to establish intonation contours can thus be interpreted as follows:

- When $S$ and $K$ seem to agree on topics, or when $K$ seems about to accept $S$ 's treatment of the problem, i.e. when a solution to the problem does not seem to be far away, $S$ uses the same contour types as $K$ does, bringing his intonation close to $K^{\prime}$ s. When, on the other hand, $S$ 's and $K^{\prime} s$ views and expectations are simply presented as being in conflict, and a solution seems far away, $S$ moves his intonation away from $K$ s. Local modifications of accents seem to further emphasize this divergence in turns where the solution to the problem seems farthest away.

- Interactively, a convergence of intonation seems to signal an interactive meaning, which might be paraphrased as "Let's go further in this direction!". By contrast, a divergence of intonation seems to signal "Stop! You are going too far in the wrong direction! Come back in my direction!". In this sense, the use of intonation contours as part of speech style fulfils functions in the control and manipulation of conversational development.

In conclusion, the differential use of high level tone intonation and the differential use of intonation contours, in combination, seem to provide powerful, adjustable strategies to control conversational development, and to constitute and signal reciprocity.

In contrast to its use for signalling local conversational problems, intonation is not used as a distinctive contextualization cue in the more global strategy described in this section. Nevertheless, in order to explicate the formal features and structures on which participants' and analysts' functional interpretation of the status and function of turns relies, it is here, too, a necessary component. Its neglect would only have allowed the interpretation that the speaker consistently tries to urge the recipient to accept his solution of the problem; we would not be able to differentiate between the reformulations on formal grounds.

\section{Conclusions}

In the preceding analyses, I hope to have shown that intonation is used in conversations as one cue (co-occurring with other cues on other levels) to contextualize an utterance within local and/or global conversational sequences. Intonation thus signals and constitutes those sequences' status as specific 
turns within a conversational context in which the recipient is expected to react in specific expected or conditionally relevant ways. Although in most cases intonation co-occurs with other cues (such as syntactic structure and the position of conversational turns), in at least some cases it is intonation only that differentiates otherwise identical utterances in identical contexts and thus functions as a distinctive cue with respect to the signalling of the meaning and function of utterances. In other cases, when intonation is not used as a distinctive cue, it is nevertheless an important formal feature which needs explication in our functional interpretation of utterances in conversations.

These results point to the necessity of systematically incorporating the analysis of prosody and intonation into the conversational analysis of interaction. If the aim of conversational analysis is to make explicit the formal and structural bases of speaker-recipient interaction, this cannot be achieved by the analysis of the lexical component of interaction alone. In particular, the re-analysis of so-called repair sequences demonstrates that an analysis incorporating prosody and intonation leads to much deeper insights into the internal structure of these sequences than an analysis neglecting these features (see Selting (1987b)).

\section{References}

Couper-Kuhlen, Elizabeth, 1983. Intonatorische Kohäsion. Eine makroprosodische Untersuchung. Zeitschrift für Literaturwissenschaft und Linguistik (LiLi) 49: 74-100.

Couper-Kuhlen, Elizabeth, 1986. An introduction to English prosody. Tübingen: Niemeyer.

French, Peter and John Local, 1983. Turn-competitive incomings. Journal of Pragmatics 7: 17-38.

Gibbon, Dafydd, 1984. 'Intonation as an adaptive process'. In: Dafydd Gibbon and Helmut Richter, eds., Intonation, accent and rhythm. Studies in discourse phonology. Berlin/New York: de Gruyter, pp. 165-192.

Gibbon, Dafydd and Margret Selting, 1983. Intonation und die Strukturierung eines Diskurses. Zeitschrift für Literaturwissenschaft und Linguistik (LiLi) 49: 53-73.

Goldberg, Jo Ann, 1979. 'Amplitude shift. A mechanism for the affiliation of utterances in conversational interaction'. In: Jim Schenkein, ed., Studies in the organization of conversational interaction. New York: Academic Press. pp. 199-218.

Gülich, Elisabeth and Thomas Kotschi, 1985. 'Reformulierungshandlungen als Mittel der Textkonstitution. Untersuchungen zu französischen Texten aus mündlicher Kommunikation'. In: Wolfgang Motsch, ed., Satz, Text, sprachliche Handlung. Berlin (DDR): Akademie-Verlag (Studia Grammatica 25). pp. 199-261.

Gumperz, John, 1982. Discourse strategies. Cambridge: Cambridge University Press.

Jefferson, Gail, 1981. 'The abominable $N e$ ? An exploration of post-response pursuit of response'. In: Peter Schröder and Hugo Steger, eds., Dialogforschung. Jahrbuch 1980 des Instituts für deutsche Sprache. Düsseldorf: Schwann. pp. 53-88.

Schegloff, Emanuel A., Gail Jefferson and Harvey Sacks, 1977. The preference for self-correction in the organization of repair in conversation. Language $53: 361-382$.

Selting, Margret, 1985. Levels of style-shifting. Exemplified in the interaction strategies of a moderator in a listener participation programme. Journal of Pragmatics 9:179-197.

Selting, Margret, 1987a. Verständigungsprobleme. Eine empirische Analyse am Beispiel der Bürger-Verwaltungs-Kommunikation. Tübingen: Niemeyer. 
Selting, Margret, 1987b. Reparaturen und lokale Verstehensprobleme. Oder: Zur Binnenstruktur von Reparatursequenzen. Linguistische Berichte 108: 128-149.

Selting, Margret, 1987c. Fremdkorrekturen als Manifestationsformen von Verständigungspro blemen. Zeitschrift für Sprachwissenschaft 6(1): 37-58.

Selting, Margret, 1987d. Descriptive categories for the auditive analysis of intonation in conversation. Journal of Pragmatics 11(6): 777-791.

Thakerar, Jitendra, Howard Giles and Jenny Cheshire, 1982.'Psychological and linguistic parameters of speech accommodation theory'. In: Colin Frazer and Klaus R. Scherer, eds, Advances in the social psychology of language. Cambridge: Cambridge University Press. pp. 205-255.

Thrane, Torben, 1980. Referential-semantic analysis. Aspects of a theory of linguistic reference. Cambridge: Cambridge University Press.

Yule, George, 1980. Speakers' topics and major paratones. Lingua 52: 33-47. 